\title{
Sciendo
}

Administration, vol. 68, no. 4 (2020), pp. 7-26

doi: 10.2478/admin-2020-0021

\section{Hindsight, insight and foresight: Some reflections on reforming the public service}

\author{
Richard Boyle \\ Institute of Public Administration, Ireland
}

\begin{abstract}
This article starts off by presenting a brief history of public service reform initiatives in Ireland, at both central and local government level, from the foundation of the state to the present day. Reasons for the reforms and the main issues addressed are highlighted. Common themes are identified. These common themes provide the basis for identifying and examining five enduring reform challenges: building the capability of public servants; involving and empowering the public; coordination and collaboration; centralisation versus decentralisation; and policy and evidence. Drawing from insights from previous reform efforts, and particularly those following the financial crisis, suggestions are made as to what steps might be taken in the next phase of reform to deal with them.
\end{abstract}

Keywords: Public service, reform, central government, local government, Ireland

At my final interview for the post of research officer in the Institute of Public Administration, in the summer of 1986, I was asked if I had any comments on the then relatively recently published White Paper on public service reform, Serving the Country Better. At the time, I didn't know that the questioner, Paddy Moore from the Department of 
Finance, was one of the authors of the paper. My response was generally positive, but I did say that the section on customer service seemed to lack somewhat in ambition, with one of the main highlights being that public servants directly serving customers should have name badges! Thankfully, my criticism wasn't held against me, and I started work for the Institute in September 1986. I have been involved since then in exploring the implications of reform programmes for the delivery of public services both in Ireland and internationally. This article contains some personal reflections on public service reform initiatives, alongside some thoughts on where reform should go in the future. It starts with a historical overview of reform, followed by reflections on five enduring reform challenges.

\section{Hindsight - A (very) brief history of reform efforts}

Table 1 lists the main overarching public service reform initiatives at central and local government level since independence. I have not included sectoral reform efforts in areas such as health, education, justice, etc.

\section{Table 1: Central and local government public service reform initiatives in Ireland}

\begin{tabular}{lcl}
\hline Reform initiative & Year & Main themes \\
\hline Brennan Commission & $1932-5$ & Maintain existing structures and arrangements. \\
\hline $\begin{array}{l}\text { Report of the Public } \\
\text { Services Organisation } \\
\text { Review Group 1966-1969 } \\
\text { (Devlin report) }\end{array}$ & 1969 & $\begin{array}{l}\text { Structures, management and planning, } \\
\text { separation of policy and execution. }\end{array}$ \\
\hline $\begin{array}{l}\text { Local Government } \\
\text { Reorganisation }\end{array}$ & 1971 & $\begin{array}{l}\text { Abolition of sub-county structure, service } \\
\text { consolidation, rationalisation. }\end{array}$ \\
$\begin{array}{l}\text { Serving the Country Better } \\
1985\end{array}$ & $\begin{array}{l}\text { Management systems, responsibility for results, } \\
\text { customer service. }\end{array}$ \\
$\begin{array}{l}\text { The Reform of Local } \\
\text { Government: Policy }\end{array}$ & 1985 & Structures, devolution. \\
$\begin{array}{l}\text { Statement } \\
\text { Local Government } \\
\text { Reorganisation and Reform: } \\
\text { Report of the Advisory } \\
\begin{array}{l}\text { Expert Committee } \\
\text { (Barrington report) }\end{array}\end{array}$ & $\begin{array}{l}\text { Constitutional recognition of local government, } \\
\text { structures, devolution. }\end{array}$ \\
\hline
\end{tabular}




\section{Table 1: Central and local government public service reform initiatives in Ireland (Contd.)}

\begin{tabular}{|c|c|c|}
\hline Reform initiative & Year & Main themes \\
\hline $\begin{array}{l}\text { Strategic Management } \\
\text { Initiative }\end{array}$ & 1994 & $\begin{array}{l}\text { Strategy for national development, service to } \\
\text { the public, efficient use of resources. }\end{array}$ \\
\hline $\begin{array}{l}\text { Delivering Better } \\
\text { Government }\end{array}$ & 1996 & $\begin{array}{l}\text { Management structures, human resource } \\
\text { management, financial management, } \\
\text { information technology. }\end{array}$ \\
\hline $\begin{array}{r}\text { Better Local } \\
\text { Government }\end{array}$ & 1996 & Structures, strategic planning, corporate plans. \\
\hline $\begin{array}{ll} & \text { Public Service } \\
& \text { Management Act }\end{array}$ & 1997 & $\begin{array}{l}\text { Responsibility and accountability of ministers } \\
\text { and civil servants. }\end{array}$ \\
\hline $\begin{array}{l}\text { Transforming Public } \\
\text { Services }\end{array}$ & 2008 & $\begin{array}{l}\text { Governance and structures, e-government, } \\
\text { citizen engagement. }\end{array}$ \\
\hline $\begin{array}{l}\text { Stronger Local Democracy: } \\
\text { Options for Change }\end{array}$ & 2008 & $\begin{array}{l}\text { Structures, devolution, greater public } \\
\text { involvement. }\end{array}$ \\
\hline Public Service Reform Plan & 2011 & $\begin{array}{l}\text { Efficiency and cost reduction, alternative service } \\
\text { delivery, rationalisation. }\end{array}$ \\
\hline $\begin{array}{l}\text { Putting People First: Action } \\
\text { Programme for Effective } \\
\text { Local Government }\end{array}$ & 2012 & $\begin{array}{l}\text { Structures, funding accountability and } \\
\text { governance arrangements, involvement in } \\
\text { economic development and job creation, } \\
\text { efficiency. }\end{array}$ \\
\hline $\begin{array}{l}\text { Public Service Reform Plan } \\
\text { 2014-2016 }\end{array}$ & 2014 & $\begin{array}{l}\text { Improved outcomes, reform dividend, } \\
\text { digitalisation/open data, openness and } \\
\text { accountability. }\end{array}$ \\
\hline Civil Service Renewal Plan & 2014 & $\begin{array}{l}\text { Structures, capacity and capability, openness } \\
\text { and accountability. }\end{array}$ \\
\hline Our Public Service 2020 & 2017 & $\begin{array}{l}\text { Service delivery, innovation, people } \\
\text { management. }\end{array}$ \\
\hline
\end{tabular}

\section{Reform initiatives before the global financial crisis - 1932 to 2008}

The Brennan Commission on the Civil Service (1932 to 1935) was the first body to examine the workings of the civil service following the foundation of the state. The commission took an essentially conservative and minimalist approach to the question of administrative reform (O'Toole, 2015). This approach is perhaps well reflected in a quote that, thankfully, would not see the light of day today, where the report noted there was 'special reason for supposing that on the whole, when all relevant aspects are taken into account, the woman does not give as good a return of work as the man'. 
The next review of the civil service, and indeed the first examination of the public service as a whole, was not to take place until 1966 when the Public Services Organisation Review Group was set up under the chairmanship of Liam St. John Devlin, a prominent businessman. The Devlin report took a more critical stance on the public service and its performance, highlighting concerns about structure, management and planning. The report recommended the reorganisation of departments into policy (Aireacht) and executive areas, and the creation of a new Minister and Department of the Public Service. As Murray (2001) notes, there was little political support developed to carry through the recommendations, nor did the civil service or wider public service champion the change agenda.

A Government White Paper titled Local Government Reorganisation was published in 1971. This proposed the abolition of the sub-county structures and their replacement with area committees, consolidating services at the county level. It also proposed the merger of Waterford city and county, a single authority for Dublin city and county, and greater coordination between city and county in Cork and Limerick. The recommendations were not implemented, though many resurfaced in later reforms.

We then have to wait until the 1980s and the production of the White Paper Serving the Country Better in 1985 for the next concerted reform initiative. While the economic downturn of the time limited the implementation and impact of recommendations such as the creation of executive offices (echoing Devlin), some of the initiatives subsequently took root. These include the introduction of management committees at the top level in organisations, and more of a focus on specifying aims and objectives, referred to as managing for results. (As an aside, my first published article on reform was on the topic of managing for results in the journal Seirbhis Phoibli. It was chosen as the topic to adorn the cover page, which was by way of a cartoon depicting the subject by Martyn Turner of The Irish Times fame. The original has hung proudly on the wall in my office since then!)

The year 1985 also saw the publication of The Reform of Local Government: Policy Statement, a statement on local authority reform by the then Minister for the Environment (Kavanagh, 1985). This report proposed new sub-county structures, the subdivision of Dublin County Council into three new councils, and devolution of some services from central to local government. Most of the recommendations were not acted on, though some were taken up later. 
The next local government reform effort came with the publication of the report of the Advisory Expert Committee on local government reform, commonly referred to as the Barrington report after its chair, and former Director of the Institute of Public Administration, Tom Barrington (Advisory Expert Committee, 1991). Their proposals included constitutional recognition for local government, reform of structures at sub-county and regional level, and devolution of new powers to local authorities. As noted in Callanan (2018), the response was piecemeal.

The initiation of the Strategic Management Initiative (SMI) in 1994 heralded the start of an era of more concerted efforts to reform the public service, and certainly a greater degree of drive and commitment from within the public service than had been seen heretofore. A Coordinating Group of Secretaries was established to oversee the development of practice with regard to strategy processes and statements, and make recommendations for management changes. An extensive support structure working on different aspects of reform, including the establishment of groups of assistant secretaries and of front-line workers, was put in place. As one of the main architects of the initiative, Eric Embleton in the Department of Finance noted, 'Centrally devised and driven programmes can meet with strong opposition, primarily because of a view of reform being imposed. The approach on this occasion was, and remains, characterised by extensive consultation with and involvement of management across the public service' (Embleton, 1999, p. 7). International reform efforts, driven by what was then being dubbed the New Public Management, were also a driving force (Boyle, 1995).

Particularly influential were the findings of a group of assistant secretaries tasked with taking account of the results of research on reforms in the New Zealand and Australian public service (Byrne et al., 1995). Their work supported the drafting of Delivering Better Government (DBG) in 1996. DBG proposed a new management structure and new approaches to human resource management, a more integrated performance management process, reform of the financial management system and effective use of information technology. In assessing progress, Murray (2001) reported a mixed picture, 'Measured against its vision, SMI's vision is infinitely approachable and progress has been made. Considering the five essential elements of the DBG framework for change, the assessment is mixed and concern is directed to the silence around delivery of better quality of policy advice and the ability to deal with "wholegovernment" issues'. 
Also prompted by the SMI was reform of local government. Better Local Government, published in 1996, led to constitutional recognition of local government in 1999 and reformed internal structures of local government to enhance the policy role of elected members. It also emphasised the need for strategic planning and corporate plans in local government, and established strategic policy committees composed of local interests. While a number of reforms were consolidated under the Local Government Act, 2001, the impact of DBG varied considerably across local authorities (Boyle et al., 2003). Also, despite the subsequent creation of a Devolution Commission in 1997, it did not have any notable impact on the limited range of functions undertaken by local government.

The SMI also led to legislative change, with the introduction of the Public Service Management Act, 1997. The Public Service Management Act aimed to bring greater clarity to the relationships between ministers, secretaries general, programme managers and special advisers. Under the Act, ministers retain overall responsibility for government departments and offices. Secretaries general have authority, responsibility and accountability for a range of issues, including the management of the department, preparation and submission of a strategy statement, and determining how responsibilities are to be assigned to other officers in the department. The secretary general is accountable to the minister for the tasks assigned under the management structure. Nevertheless, despite these clarifications on relative responsibility and accountability between ministers and civil servants, there inevitably remained a degree of ambiguity (Boyle \& MacCarthaigh, 2011).

The SMI and related developments underpinned management structures and processes throughout the economic recovery and at the height of the Celtic Tiger. But as McCarthy (this issue) states, this economic success brought with it a lessening of the impetus for further reform, and a sense that an external stimulus was needed to further modernisation of the public service. Consequently, the OECD was invited to conduct a review of the Irish public service, and benchmark it against international practice (a relationship with the OECD that continues to the present day). The OECD reported in 2008 and, while they found much to commend with regard to management practices in Ireland, they also noted that 'despite the reforms, the overall political and managerial systems in Ireland are still based on a compliance culture that emphasises controlling inputs and following rules' (OECD, 2008, p. 170), and went on to recommend that future reform 
'is not about changing structures and systems, but is primarily about getting people to think and work outside of institutional boundaries' (p. 267).

The immediate response to the OECD review was the publication of Transforming Public Services at central government level and Stronger Local Democracy: Options for Change, a Green Paper on local government reform, both in 2008. Following the publication of Transforming Public Services (Department of the Taoiseach, 2008), the government established a cabinet committee on transforming public services, appointed a minister of state with responsibility for public service transformation, and set up a programme office in the Department of the Taoiseach. Stronger Local Democracy: Options for Change had a focus on stronger democratic processes and improving the balance of powers between management and elected representatives, including the establishment of a system of directly elected mayors. The Green Paper also called for a greater devolution of local decisions from county council to town council level, and advocated an enhanced role for people in local decision-making (Department of the Environment, Heritage and Local Government, 2008). While some aspects of the reforms outlined in Transforming Public Services and Stronger Local Democracy: Options for Change were to reappear in subsequent reform initiatives, the financial crisis that hit the state in 2009 effectively put paid to any thoughts of implementation.

\section{Reform initiatives after the global financial crisis - 2011 to 2020}

This brings us to the time which is the main focus of this issue, reform post the crisis. Prior to the financial crisis, as several commentators, including in this issue, have noted, public administration reform in Ireland was primarily administratively driven. While there was general political support for the reform initiatives, and strong push from individual ministers such as John Boland in 1985 and Albert Reynolds when Taoiseach at the time of the SMI, by and large the main drivers were managers in the public service. For example, the SMI and subsequent DBG reform plan of the mid 1990s, which steered reform initiatives for the next decade, arose in large part from senior civil servants realising that reform was taking place in other countries, and a sense that Ireland needed to be a part of this process.

One thing that the financial and economic crisis changed was that it created a climate where there was much stronger public and political pressure for public service reform. While, as Watt \& Perkins state in this issue, the demand for reform was inchoate and often simplistically 
focused on an unsubstantiated view that a 'bloated' public service existed in Ireland, nevertheless reform of the public service, pretty much for the first time, was a significant issue in the election campaign of 2011. The government elected then had a strong mandate for reform. This was supported by the external monitoring of reform efforts by the troika of the European Commission, European Central Bank and International Monetary Fund in the context of the financial assistance provided to Ireland. The new Department of Public Expenditure and Reform became a key driver for reform (MacCarthaigh, this issue). Issues such as governance structures and processes also became more prominent (Horan \& Mulreany, this issue).

One of the outcomes of this renewed focus on reform was the publication of the Public Service Reform plan (Department of Public Expenditure and Reform, 2011). The plan addressed a wide range of issues such as the implementation of shared services models for areas such as HR, payroll and pensions; reform of public procurement; the development of alternative service delivery models; and reducing costs, addressing duplication and eliminating waste. In line with the response to the financial crisis, the emphasis was on rationalisation and, where possible, reductions in expenditure. A review carried out a couple of years after the plan was introduced indicated that managing the scale of reductions in numbers and pay across the public service without major disruption to services at a time of population increase had been a significant achievement. But challenges and limitations were also identified, including ensuring that there are people of the right calibre and with the competencies needed to manage and deliver the public service of the future (Boyle, 2013).

At the local government level Putting People First: Action Programme for Effective Local Government (Department of the Environment, Community and Local Government, 2012) was published. At the sub-county level, it proposed the abolition of town councils, to be replaced by a system of municipal districts. The position of city/county manager was to be replaced with a chief executive. Local authorities were to take on a more significant role in relation to economic and community development, and have new funding arrangements. There was a commitment to end the policy of establishing central government structures and agencies to deliver services at the local level. Many of these initiatives were acted on, apart from the commitment to less central involvement in the delivery of local services (Callanan, this issue), and given statutory authority under the Local Government Reform Act, 2014. 
As the fiscal situation improved, there was recognition both politically and administratively that a further phase of reform was needed, with more of a focus on improving outcomes for stakeholders, including citizens, businesses and public servants. Consequently, the Public Service Reform Plan 2014-2016 (Department of Public Expenditure and Reform, 2014a) was developed and published. This had four main themes: delivery of improved outcomes; a reform dividend; digitalisation/open data; and openness and accountability. The OECD was asked to review the impact of the plan. The review found that 'there remains a strong emphasis on achieving cost reductions and efficiencies through its cross-cutting actions. While this is positive, more could have been done to help the plan realise its message of achieving better outcomes for all stakeholders' (OECD, 2017, p. 1).

At central government level, the need for a plan specifically for the whole of the civil service was identified as a priority, and this led to the publication of the Civil Service Renewal Plan (Department of Public Expenditure and Reform, 2014b). The plan identified four priority areas with associated actions: a unified civil service; a professional civil service; a responsive civil service; and an open and accountable civil service. A particular emphasis was put on building the capacity and capability of civil servants.

The OECD review in 2017 heralded the introduction of the most recent reform initiative, Our Public Service 2020 (Department of Public Expenditure and Reform, 2017). This plan is built on three pillars: delivering for our public; innovating for our future; and developing our people and organisations. A particular emphasis was put on the concept of innovation, and identifying new ways of working and delivering services.

\section{Insight and foresight - Addressing five enduring reform challenges}

In examining reform initiatives, it is clear that some issues recur. They may be thought of as enduring challenges that each generation of reformers has to address. They often feature, in one way or another, in any public service reform plan or programme. Here, I look at five such issues. Drawing from insights from previous reform efforts, and particularly those following the financial crisis, I try to give a sense of why these issues are important, and some suggestions as to what steps might be taken in the next phase of reform efforts to deal with them. 


\section{Building the capability of public servants}

The late Christopher Pollitt once wrote that at the core of many reform efforts is an 'underlying belief that changing organisational structures and processes can and will change the effectiveness of government' (Pollitt, 2013). What he understood is that this belief alone is not enough, and misses the critical role played by the people who have to operate the structures and processes. One thing I have learned in examining and participating in reform initiatives over the years is the importance of skilled and competent people. Good people can make imperfect systems, structures and processes work. If you have the wrong people in the job, no matter how good the structures or processes, the outcome will be less than optimal. The capability and competence of public servants is at the heart of good public administration.

There have been significant developments in human resource management over various reform initiatives, and much has been done regarding capability development. Major staffing changes arose post the financial crash, with reductions in staff numbers and early retirement leading to the loss of a number of senior and experienced people. People management subsequently became a notable feature of reform initiatives such as the Public Service Reform Plan 2014-2016, the Civil Service Renewal Plan and Our Public Service 2020. Nevertheless, efforts have been somewhat 'patchy' and there is always more that needs to be done and improvements to be made. Indeed, Roche (2013, p. 217) has critiqued previous reform efforts in the human resources area as 'little more than a bunch of ill-coordinated initiatives bound together by a series of clichés'. While his conclusions in this issue (Roche \& O'Riordan) are somewhat more tempered, it is clearly an area where more work is required. What is clear is that, looking to the future, recruitment, retention and development of public servants will remain vital to the success of, and be a key element of, any reform efforts (Dickinson et al., 2019).

Looking to recruitment first, there is now a more open and structured recruitment process. With regard to competencies and skills, as Watt \& Perkins (this issue) note, there is an increasing trend to more use of specialist staff. The use of more open recruitment, a greater role for 'outsiders' and more specialisation and professionalisation in the public service is likely to continue. Whilst having benefits and bringing about a more diverse and specialised skills base, this will bring its own challenges. In countries such as the UK and the US, which has promoted open recruitment and employment of senior 
managers from outside the public service for a number of years, there have been issues around higher levels of turnover and difficulties for some outsiders in adjusting to the organisational culture and practice of the public service and in identifying with a public service ethos.

What is needed is an appropriate balance between specialists and generalists, outsiders and insiders. It is also important that the diversity of public service staff reflects the diversity of Irish society. This is easier to say than to make happen. It requires constant scrutiny of the required skill mix and demands facing the public service. It is essential that in the quest to develop more specialisms, of which the Irish Government Economic and Evaluation Service is a positive example, the need to recruit and develop good people with generalist skills is not lost. There will always be a need for the appointment and nurturing of people skilled in policy advice and the provision of wise counsel, who can operate at the interface between the political and administrative domains. This is not to say that specialists cannot develop these skills, just that a mix is needed.

Regarding retention, issues of pay and conditions need to be considered alongside more intangible elements such as building and maintaining public service motivation. In general, the pay agreements developed post the financial crisis have served the state well, though not without their challenges (Roche \& O'Riordan, this issue). With regard to public service motivation, O'Riordan (2013) stresses the need to promote public service values and align incentives with intrinsic motivations.

Staff development can have a significant influence on retention, alongside its wider role in building capability. Generally, more attention needs to be given to talent management and succession planning. There is far too little regard for transferring the knowledge and skills of departing public servants at all levels. One noteworthy issue for the future is that of distributed leadership, promoting the concept of leadership at all levels. Distributing leadership across levels and organisations builds the capacity for change. As a leadership model, it moves away from a simple view of leadership from the top to more collaborative and shared leadership (Boyle et al., 2019). In particular, public service organisations need to put more effort into developing middle management change-management capabilities. One excellent way of doing this is through selecting middle managers to lead out on important cross-cutting projects, but also specifically use this as a developmental opportunity, providing them with the supports needed to learn on the job. An alternative or complementary 
approach is to use secondments to a central unit, such as was done in the Prime Minister's Delivery Unit (Thomas, this issue).

\section{Involving and empowering the public}

The financial crisis led to a significant loss of trust of the public in government and its capacity to manage the economy and deliver services effectively and efficiently. Rebuilding trust has in part been addressed by an increasing focus on involving the public in policy and implementation decisions in recent reform initiatives. Public engagement, for example, is being addressed at a number of levels. Open policy debates to involve policy networks of practitioners, academics and experts on key issues were introduced in 2015 under the Civil Service Renewal Plan. Public participation networks, established in all local authority areas, aim to ensure that stakeholder voices have a stronger role in decision-making at local level, though with mixed results to date. Regular, structured customer surveys at both central and local government level are providing a better picture of user experiences, expectations and levels of satisfaction.

Looking to the next phase of reform, digital and e-government will continue to grow in prominence, and how this will affect the public needs consideration. What Dunleavy et al. (2006) refer to as digital era governance will be more prominent in shaping the interaction between government and civil society. This will be accompanied by the need for a more agile and adaptable public service. The public are increasingly likely to want to do things like manage their own tax accounts, examine their medical and other files and so on, with the need for systems and processes that support such activities.

With regard to public engagement, the demand to go beyond information provision and consultation to involvement, collaboration and empowerment of the public in service provision will continue to build. Initiatives at central and local government level will be important here in determining a future where the public have a greater voice in shaping policy and practice (Shannon \& O'Leary, 2020). User-driven services, where the public work with practitioners and professionals to co-produce services, have the potential to improve service quality, be cost-effective, make for more appropriate services and increase people's satisfaction with public services. As Healy \& Clarke (this issue) show, the voice of people who use public services needs to be at the heart of efforts to implement reforms. But there is still some way to go to making co-production a fundamental principle of service delivery and design. 


\section{Coordination and collaboration}

A desire for better coordination and collaboration, both horizontally (across organisations) and vertically (across levels of government), is a constant theme of reform initiatives (O'Flynn et al., 2013). This can go beyond a whole-of-government approach, as the actors involved will often include third sector organisations and the private sector. Two decades ago, my former colleague Peter Humphreys and I wrote that the management of cross-cutting issues was one of growing prominence for the public service (Boyle \& Humphreys, 2001). We noted three particular challenges, which remain pertinent today: getting policy design right; determining appropriate service delivery mechanisms so that, from a user's perspective, a 'seamless service' is provided; and providing sound evaluative information to enable judgements to be made regarding progress in addressing the issue under scrutiny.

Initial reform efforts post the financial crisis in this space emphasised the development of shared services for back office functions, to promote more coordination and cohesion. Subsequent reform plans have put an emphasis on better integration of services so as to provide better outcomes for the public. The theme of Action 9 of Our Public Service 2020 (Department of Public Expenditure and Reform, 2017) is strengthening whole-of-government collaboration, emphasising the need for action at both central government and local government levels.

Looking forward, I highlight here two potential initiatives under this theme that I see as being of particular importance. One is an issue I have raised previously with little success to date. Learning from some international examples such as public service agreements in the UK (Thomas, this issue), cross-agency priority goals in the US (Kamensky, 2017) and New Zealand's 10 Results initiative (Scott \& Boyd, 2017), there are clear benefits to be achieved by identifying, agreeing and focusing on a small number of policy outcome-focused goals. This requires political direction to agree a small number of achievable cross-cutting goals, which require action across organisations and levels of government, such as reducing obesity or reducing the level of rough sleeping, and then setting in place the people, structures and processes to pursue these goals and report back on progress.

The second initiative is to design approaches to governance that can secure strong legitimacy and accountability for networks of organisations that encourage creativity and experimentation. What has been termed an experimental governance approach offers promise 
here. Sabel \& Zeitlin (2012) note that experimental governance involves a multilevel architecture, with four elements linked in an iterative cycle: setting of framework goals; discretion to lower levels regarding implementation; regular reporting and assessment; and periodic review of the framework goals. It is particularly important that general and not too specific goals are set, that experimentation at the local level is encouraged to achieve these goals, and that lessons learned are reported, disseminated and acted on (Sabel et al., forthcoming).

\section{Centralisation versus decentralisation}

As Callanan, McCarthy, and Umfreville \& Sirr (this issue) all note, there has been a preference for centralised approaches to issues, with local government being seen as something of a poor relation - despite numerous commitments in reform programmes to increasing decentralisation and devolution of functions to the local level. In practice, the global financial crisis led to a further increase in centralisation of power and authority in what was already a highly centralised state. Horizontal and vertical coordination mechanisms involving the centre of government were strengthened. MacCarthaigh (this issue) notes that the organisation of Irish political-administrative governance is such that hierarchical approaches have tended to dominate reform efforts. When in doubt, the tendency in reform efforts is to centralise.

There is also a low level of interaction overall between central government and regional and local government officials. Almost half of senior officials surveyed, as part of an EU-wide survey, said they never interact with local and regional government, and a further quarter interact only yearly (Boyle, 2014). These levels of interaction are lower than in many other European countries. There is also a much lower perceived level of coordination between national and local and regional government in Ireland (18 per cent seeing coordination as rather good versus 40 per cent for the rest of the EU countries sampled). This probably in part reflects the relatively higher status and range of functions carried out by local government in many other European countries.

While the lessons from history suggest that it will not happen, nevertheless I suggest that the logic for greater devolution of functions to local government is compelling. It should be a feature of future reform efforts. Going back to the advocacy of the IPA's first director, Tom Barrington, the Institute has been a strong supporter of a more 
prominent role for local government in public life. We have not got the balance right to date between what should remain controlled centrally and what is best done locally. Other small European states show that a better balance can be achieved in an effective and efficient manner. Why we constantly fail to heed this lesson is one of the mysteries I have grappled with during the course of my time at the Institute.

\section{Policy and evidence}

The dominant theme of my own research over many years has been performance measurement, management and evaluation. In many instances, the outcomes achieved by public services are notoriously difficult to measure and evaluate. Multi-year timescales, competing, conflicting and vague objectives, and challenges with identifying the contribution of individual policies and programmes all make the provision of good evidence challenging. Add in an increasing public and political scepticism for the role of experts in providing evidence, and the emergence of what has been termed the post-truth era with its alternative facts, and things do not look too promising. Yet my experience would suggest that it is unwise to give in to a counsel of despair. The need for evidence to inform policy is as strong as ever, steps can be taken, and new sources of evidence are emerging all the time. The challenges will always be there but, as in the criminal justice realm, good, sound evidence, even when incomplete, can prove invaluable to informing judgements.

With regard to developing and using evidence, the financial crisis showed that we needed a better understanding of what was being achieved by expenditure programmes so as to know what to protect and what to cut when resources run scarce. Some notable reforms have taken place to address this matter in recent years. In particular, the introduction of a Public Spending Code, creation of an Irish Government Economic and Evaluation Service across all government departments, and introduction of spending reviews are amongst the welcome measures aimed at strengthening the use of evidence in the budgeting and management of expenditure programmes. Moving beyond expenditure review, McNamara et al. (this issue) show how in the education sector, through persistent efforts over many years, evidence from school inspections and school self-evaluation has led to improved school practices.

Looking forward, there is a need to address both the supply of and the demand for evidence. Most reform initiatives to date have tended 
to focus, naturally enough, on the supply side. Taking steps to try to improve the effective demand for and use of evidence by policymakers and politicians is equally important, and future reform efforts should give more attention to this issue. Experience indicates that policymakers and politicians make more effective use of evidence when they receive supports in helping them make sense of and interpret the evidence. Knowledge brokers, sometimes in the form of intermediary organisations (such as the Parliamentary Budget Office), have an important role to play here in supporting access to relevant material and facilitating the identification and understanding of the main messages. Moynihan (2017, p. 13) shows that the use of anecdotes or stories to supplement the presentation of data makes evidence memorable, and consequently more influential.

A further driver of evidence use is to establish regular structured reviews. These provide fora where evidence can be considered and discussed, rather than just sitting on a laptop or report. To take the example of the US cross-agency priority goals mentioned above, a system of formal quarterly reviews was institutionalised, with an emphasis on learning and sharing successes and challenges.

\section{Conclusions}

As Pollitt \& Bouckaert (2011, p. 30) point out in their seminal work, public service reform 'is more important than the ephemeral thrills and spills of "high politics", because it may have direct impacts on the enduring basics - education, health, crime, safety - things whose effects last far longer than the transient personalities and slogans that so often occupy the headlines'. Public service reform initiatives leave their mark on the management of public services, some more than others. Clearly, since the financial crisis in Ireland, the pace of reform has increased, with new reform plans every few years as opposed to the slower pace on reform in the twentieth century. What the effect of these reform efforts has been on the impact and legitimacy of government is open to question, though there is some evidence that, in the round, Ireland's public administration stands up reasonably well in comparison with its European neighbours (Boyle, 2020).

The financial crisis certainly gave rise to a renewed emphasis on public service reform, and gave additional political support to the planned changes. At the time of writing, October 2020, while it is too early to speculate on the precise impact, undoubtedly the Covid-19 crisis, when combined with the effects of Brexit and other global 
challenges such as climate change, will have serious implications for the future public service reform agenda, and perhaps return public service reform onto the political agenda. Issues concerning staffing, structuring and paying the public service will be revisited - as will the political-administrative interface. A bigger role for the state in running the economy is envisaged, particularly in areas like health, housing and climate action. Thought needs to be given to how the public administration as a whole can best adapt to the new circumstances. Innovative, experimental approaches to policy development and delivery will be needed, and, crucially, evaluation and feedback of the lessons learned.

The late US Supreme Court judge Ruth Bader Ginsberg once remarked that 'Real change, enduring change, happens one step at a time'. Reform of public services is a journey of one step at a time, with new initiatives building on the successes and failures of previous reform initiatives. Reform can seem a technocratic exercise, but it is not. Early in my career, I finished a short book outlining the theory and practice of public management reform with the following sentence:

As politicians and public servants make value choices and choose the management models to give expression to those values... they are determining the framework within which Irish people work out their destinies as citizens and express their personality as a community. (Boyle, 1995, p. 49)

I sometimes liken public service reform to the pursuit of the Holy Grail. You never reach the final destination, but the journey along the way is full of twists and turns, highs and lows, successes and failures. The journey continues.

\section{References}

Advisory Expert Committee. (1991). Local government reorganisation and reform: Report of the Advisory Expert Committee [Barrington report]. Dublin: The Stationery Office.

Boyle, R. (1995). Towards a new public service. Dublin: Institute of Public Administration.

Boyle, R. (2013). Fit for purpose? Progress report on public service reform. [State of the public service research series paper 9]. Dublin: Institute of Public Administration. 
Boyle, R. (2014). Public sector reform in Ireland: Views and experiences from senior executives [State of the public service research series paper 13]. Dublin: Institute of Public Administration.

Boyle, R. (2020). Public sector trends 2020. [State of the public service research series paper 26]. Dublin: Institute of Public Administration.

Boyle, R., \& Humphreys, P. C. (2001). A new change agenda for the Irish public service [CPMR research discussion paper 17]. Dublin: Institute of Public Administration.

Boyle, R., Humphreys, P. C., O'Donnell, O., O'Riordan, J., \& Timonen, V. (2003). Changing local government: A review of the Local Government Modernisation Programme [CPMR research report 5]. Dublin: Institute of Public Administration.

Boyle, R., \& MacCarthaigh, M. (2011). Fit for purpose? Challenges for Irish public administration and priorities for public service reform. Dublin: Institute of Public Administration.

Boyle, R., O'Riordan, J., Shannon, L., MacCarthaigh, M., \& Thomas, P. (2019). Evaluation of the Goal Programme for Public Service Reform and Innovation. Dublin: Institute of Public Administration.

Brennan Commission. (1935). Commission of Inquiry into the Civil Service 1932-35. Dublin: The Stationery Office.

Byrne, D., Dully, J., Garvey, D., Kirwan, W., Mulherin, T., O’Hanlon, G., Rogers, S., Ryan, O., Treacy, C., Tuohy, B., \& Tutty, M. G. (1995). Strategic management in the Irish civil service: A review drawing on experience in New Zealand and Australia. Administration, 43 (2), 1-153.

Callanan, M. (2018). Local government in the Republic of Ireland. Dublin: Institute of Public Administration.

Co-ordinating Group of Secretaries. (1996). Delivering better government: Second report to government of the Co-ordinating Group of Secretaries A programme of change for the Irish civil service. Dublin: The Stationery Office.

Department of Public Expenditure and Reform. (2011). Public service reform. Dublin: Department of Public Expenditure and Reform.

Department of Public Expenditure and Reform. (2014a). Public service reform plan 2014-2016. Dublin: Department of Public Expenditure and Reform.

Department of Public Expenditure and Reform. (2014b). Civil service renewal plan. Dublin: Department of Public Expenditure and Reform.

Department of Public Expenditure and Reform. (2017). Our public service 2020. Dublin: Department of Public Expenditure and Reform.

Department of the Environment, Community and Local Government. (2012). Putting people first: Action programme for effective local government. Dublin: Department of the Environment, Community and Local Government.

Department of the Environment, Heritage and Local Government. (2008). Stronger local democracy: Options for change. Dublin: The Stationery Office. 
Department of the Taoiseach. (2008). Transforming public services, report of the Task Force on the Public Service. Dublin: The Stationery Office.

Dickinson, H., Needham, C., Mangan, C., \& Sullivan, H. (Eds) (2019). Reimagining the future public service workforce. Singapore: Springer.

Dunleavy, P., Margetts, H., Bastow, S., \& Tinkler, J. (2006). New Public Management is dead - Long live digital-era governance. Journal of Public Administration Research and Theory, 16 (3), 467-94.

Embleton, E. (1999). Ireland: Modernising the public service. In OECD, Government of the future: Getting from here to there. Symposium organised by the OECD, 14-15 September. Paris: OECD.

Kamensky, J. (2017). Cross-agency collaboration: A case study of cross-agency priority goals. Washington, DC: IBM Center for the Business of Government.

Kavanagh, L. (1985). The reform of local government: Policy statement by Liam Kavanagh TD, Minister for the Environment. Dublin: The Stationery Office.

Moynihan, D. P. (2017). Challenges for goal-based learning in public investments: A behavioral perspective on performance information use. Paris: Public Expenditure and Budgeting Division, OECD.

Murray, J. (2001). Reflections on the SMI. Working paper 1. Dublin: The Policy Institute, Trinity College Dublin.

OECD. (2008). Ireland: Towards an integrated public service. Paris: OECD.

OECD. (2017). OECD assessment of Ireland's second Public Service Reform Plan 2014-16. Paris: OECD.

O’Flynn, J., Blackman, D., \& Halligan, J. (2013). Crossing boundaries in public management and policy: The international experience. London: Routledge.

O'Riordan, J. (2013). Public service motivation [State of the public service research series]. Dublin: Institute of Public Administration.

O’Toole, J. (2015). Civil service reform in Ireland 1922 to 2012. Unpublished $\mathrm{PhD}$ thesis, University of Liverpool, UK.

Pollitt, C. (2013). The evolving narratives of public management reform: 40 years of reform white papers in the UK. Public Management Review, 15 (6), 899-922.

Pollitt, C., \& Bouckaert, G. (2011). Public management reform. A comparative analysis - New Public Management, governance, and the neo-Weberian state. Oxford: Oxford University Press.

Public Services Organisation Review Group. (1970). An abridged version of the report of Public Services Organisation Review Group 1966-1969 [Devlin report]. Dublin: Institute of Public Administration.

Roche, B. (2013). Human resource management and public service reform. Administration, 60 (3), 211-18.

Sabel, C. F., O’Donnell, R., \& O'Connell, L. (forthcoming). Self organization under deliberate direction: Irish dairy and the possibilities of a new climate change regime. Regulation and Governance.

Sabel, C. F., \& Zeitlin J. (2012). Experimentalist governance. In D. Levi-Faur (Ed.), The Oxford handbook of governance (pp. 169-83). Oxford: Oxford University Press. 
Scott, R., \& Boyd, R. (2017). Interagency performance targets: A case study of New Zealand's results programme. Washington, DC: IBM Center for the Business of Government.

Shannon, L., \& O'Leary, F. (2020). Local government: Engaging and empowering local communities [Local government research series paper 16]. Dublin: Institute of Public Administration. 